Kiss Gabriella

nyelvtanár, SZTE BTK Francia Nyelvi és Irodalmi Tanszék

PhD hallgató, SZTE BTK Neveléstudományi Doktori Iskola

\title{
Aki a legnyomorultabb embert helyezte antropológiája középpontjába: Joseph Wresinski
}

\begin{abstract}
„Ha a legnyomorultabb ember kerül a középpontba, akkor az egész emberiséget öleljük át egyetlen emberben, akkor megtagadjuk, hogy elfordítsuk róla tekintetünket vagy hogy meghamisítsuk, amit látunk, akkor odavetjük a szeretet határvidékeire; márpedig a szeretet határtalan, nem zárkózik magába, nem korlátozza önmagát - a szeretet mindig őrültség."
\end{abstract}

(Wresinski, 2010, 30. o.)

Bizonyára igaz, hogy minden alkotó világképére, világnézetére, így életmúve létrehozására is jelentốs hatást gyakorol az a makro-és mikrotársadalmi környezet, amelyból származik. Különösen igaz ez Joseph Wresinski (1917-1988) esetében, akinek a tevékenysége semmiképpen sem értelmezhetó az életrajzi vonatkozások ismerete

nélkül. Az életmú védjegyének tekinthetö ATD (Agir Tous pour la Dignité) - Negyedik Világ Mozgalom létrehozása, múködési elvei, a fokozatosan köré épülô humán és intézményi struktúra elemeiben és összességében is elválaszthatatlanok az életpályától, minden vonatkozásban szerves egységet alkotnak.

E szerves egység legfontosabb alkotóelemei, valamint az „épitóanyagokat" habarcsként összefogó személyes világszemlélet megismeréséhez alkalmas eszköznek látszik az az interjúkötet, amely

Franciaországban az 1983-as elsó kiadás óta már újra megjelent, magyarul pedig - Szegények egyháza címmel - máig az egyetlen elérhetố mü Wresinski figyelemre méltóan gazdag életmúvéból. Az alábbiakban egy ebból kiválasztott fejezet („Evezz a nyílt vízre és vesd ki hálódat!") alapján mutatom be a szerzố antropológiájának leglényegesebb jellemzóit.

\section{Wresinski és életmúve}

$\mathrm{N}$ agyon szegény családban, lengyel apa és spanyol anya gyermekeként született a franciaországi Angers-ban. Csaknem harminc évesen szentelték pappá. A nyomor világában szerzett személyes tapasztalatai és a munkáspapok mozgalma iránti rokonszenve arra indította, hogy az evangéliumot újraértelmezve életét a társadalom kirekesztettjeinek szentelje. 1957-ben Noisy-le-Grand hajléktalantelepén a legnyo- 
morúságosabb körülmények között élő családokkal együtt létrehozta az azóta világmozgalommá terebélyesedett ATD - Negyedik Világ Mozgalmat. Ez az emberjogi civil szervezet azzal a célkitüzéssel jött létre, hogy a legnagyobb nyomorban élők számára is hozzáférhetővé váljanak a minden embert megillető gazdasági, politikai és társadalmi jogok, és hogy előmozdítsa a mélyszegénység felszámolását. Három szinten fejti ki tevékenységét: önkéntesei sorsközösséget vállalnak a nyomorban élő családokkal, a szövetségesek lazább hálója a társadalom figyelmét a mélyszegénységben élőkre irányítja, és döntéshozói szinten igyekeznek a legszegényebbek életét kedvezően befolyásoló politikai változásokat kiharcolni. Két legfontosabb alapelve, hogy a megoldás keresése és megvalósítása egyaránt csakis az érintettekkel együtt, az ő aktív részvételükkel történhet, valamint hogy a segítendők körébe kivétel nélkül mindenki beletartozzon. Müködése a mélyszegénységben élő családok köré szerveződő önkéntesek, szövetségesek és az ún. barátok hármas hálóján alapul. A szervezet nem kötődik semmiféle vallási vagy politikai csoportosuláshoz, és jelenleg a világ mintegy harminc országában fejti ki tevékenységét.

Az alapító életmüvének elismeréseképpen 1992 decemberében az ENSZ Közgyülése október 17 -ét ${ }^{1}$ a szegénység és a kirekesztés elleni küzdelem világnapjává nyilvánította.

Az életpályán kívül említést kell tennünk arról a társadalmi kontextusról is, amely a papi pályára lépő Wreinskit körülvette. Ebben az időszakban a francia katolikus egyházat egyfajta vallási megújulás jellemezte. A felvilágosodás és az 1789-es forradalom örökségeként Franciaországban a munkásmozgalom mind ideológiájában, mind a gyakorlati cselekvés terén eltávolodott a kereszténységtől. A munkásság osztállyá formálódása a keresztény eszmeiségen kívül ment végbe annak ellenére, hogy létezett egy keresztény mag és bizonyos vidékeken jelentős keresztény munkásság. Ebből a felismerésböl jött létre a Francia Misszió (Mission de France) közvetlenül a háború után, és született meg az az elképzelés, hogy segítene az újra egymásra találásban, ha a papok osztoznának a munkások életében: közöttük élnének és dolgoznának, nyíltan és tudatosan felvállalnák a munkásvilág értékeit és célkitüzéseit szakszervezeti és politikai síkon is. Ez a lelkesedés hatja át Wresinskit is, amikor szentelését követően olyan helyre kéri magát, ahol „látható módon jelen van a nyomor" (Wresinski, 2010, 95. o.).

Bár Wresinski katolikus papként alapította az ATD - Negyedik Világ Mozgalmat, a szervezet nem tartozik az egyházhoz, és a magját alkotó önkéntesek között egyaránt találhatunk különböző felekezetü keresztényeket, más vallásokhoz tartozókat és meggyőződéses ateistákat. Nem költői tehát a kérdés: Milyen világnézet - vagy mely világnézetek - és milyen módon hatottak Wresinskire, illetve az általa létrehozott Mozgalomra?

Mind szavai (ebbe a rendkívül gazdag írásos életművet is beleértjük), mind tettei bizonysága alapján ember- és társadalomképére elsősorban és alapvetően a kereszténység eszmerendszere gyakorolt döntő hatást. Ezért amikor Wresinski antropológiájáról beszélünk, elsősorban a teológiai antropológia megközelítésére kell támaszkodnunk. Ezen belül különösen relevánsnak tünik Tóth $(2006,40$. o.) értelmezését alapul venni, amely szerint

„A teológiai antropológia - ellentétben a modernség pedagógiai antropológiájával, amelynek alapgondolata az ember önmaga általi megteremtése - koroktól és kultúráktól függetlenül az embert mindig mint Isten teremtményét, sőt képmását állította középpontba."

Amikor a kereszténység szemszögéből merül fel a kérdés: „,ki és mi az ember?”, az Evangéliumok tanúsága szerint azt a választ adhatjuk: autonóm személy, Krisztus megváltottja. A személy-fogalom az első keresztény dogmák megfogalmazásának kontextusában alakult ki (Bugár M., 2013), de az ezzel szorosan összefüggő Isten-képűség „státusza” elválaszthatatlan az Ószövetség első könyvében, a Genezis teremtéstörténete alapján 
megfogalmazódott elsődleges választól (1Móz1,26): Isten képére és hasonlóságára alkotott, egyedülálló teremtmény, akinek kivételes tisztsége és felelőssége, hogy az előtte teremtett világgal és annak élölényeivel különleges kapcsolatba lépjen.

\section{Antropológiai alap: Isten képmása a szegényekben}

Wresinski antropológiája azon a kettős evidencián nyugszik, mely szerint az ember vallási-ideológiai hovatartozástól függetlenül - először is Isten képmása, s mint ilyen, végtelen és elidegeníthetetlen méltóság hordozója, másodszor pedig, hogy ez a méltóság elsősorban a társadalom által kirekesztett, leginkább kiszolgáltatott, legmélyebb szegénységben élő emberben nyilvánul meg (Leclerc, 2004). Ez a meglátás abban a krisztológiai alapszemléletben gyökerezik, mely szerint a szegények különleges módon Isten fiai a Fiúban, azaz Krisztusban. A szegénység létállapotában Isten úgy nyilatkoztatja ki magát, mint aki a legszegényebbé lett a megtestesülésben, hogy elérje a legszegényebb embert is (Begasse de Dhaem, 2011).

Az Ószövetségben kirajzolódó Isten-képmás nagy tartalmi változatosságot mutat (ld. Wolff, 2001). Bennünket itt ezek közül föként egyrészt az uralkodás (annak sajátos tartalma), másrészt a minden emberben testvért látó szemlélet kérdése foglalkoztat, valamint a szabadság, ,amely kimenti az embert a mindenkori determinációk köréből, és ezáltal Isten örökkévalóságának »megfelelöjévé« teszi, analóg értelemben” (Tóth, 2006, 56. o.).

A képmás mint az uralkodó jelenlétének szimbóluma jelen van és elfogadott az ókori Kelet számos társadalmában. Az Ószövetségben is sok helyütt felismerhető az a szemlélet, mely szerint az ember hasonló szerepet tölt be a teremtésben. A világban Istent képviseli, vagyis „uralkodói joga és kötelessége nem autonóm, hanem illusztráló jellegü" (Wolff, 2001, 199. o.). Ám az uralkodás tartalma, annak a közösség (és benne hangsúlyosan a legszegényebb és a jövevény) szolgálataként történő értelmezése olyan vonás, amely éles határvonalat húz a zsidóság és a kor összes többi népe közé. Az Ószövetség releváns könyvein végigvonul az a vízió, hogy az embert mint Isten képmását szakadatlanul fenyegeti az a kísértés, hogy ha annak valódi és Istentől eredeztetett tartalmáról megfeledkezik, akkor szükségszerüen kicsúszik kezei közül az uralkodás, és - amint az a Prédikátor könyvében olvasható - a másik ember rovására elkövetett hatalmaskodássá válik (8. fejezet 9. vers). Az uralkodás, és azon belül az urak és szolgák viszonyának értelmezését Wolff szerint már az Ószövetségben is forradalminak lehet nevezni, az Újszövetség tanításában pedig ez a forradalmi szemlélet a maga teljességében bomlik ki. A zsidó nép „eredetmítoszának” föszereplői nem ünnepelt és erőskezű királyok, hanem egyrészt Isten, aki elsősorban Szabadító, másrészt pedig az az Egyiptomból menekülö rabszolgacsoport, amely mellett mint Szabadító elkötelezte magát.

Az uralkodás tehát semmiképpen sem jelentheti egyik embernek a másik felett gyakorolt hatalmát, épp ellenkezőleg: a gyengék, kiszolgáltatottak, kitaszítottak iránti segítségnyújtásban kell megnyilvánulnia. Ennél is tovább mennek azok a prófétai szövegek, amelyekben az igazi király a szokásos ikonográfiával homlokegyenest ellenkező módon mint „fájdalmak férfia, betegség ismerője..., megvetett” (Ézsaiás 53,3) fedi fel magát, s amelyben később a keresztény tanítás egyértelműen Krisztust ismeri fel.

A testvériség motívuma különböző relációkban jelenik meg a zsidóság életét szabályozó ószövetségi könyvekben. Elöször is testvérnek kell tekinteni mindenkit, aki a zsidó néphez tartozik. İgy a hitelező is testvérként bánjon adósával, csakúgy, mint a gazdag ember a nincstelennel. A korabeli társadalmakban megszokott szemlélettöl eltérően a társadalmi hierarchiában egymástól óriási távolságra elhelyezkedő csoportok viszonyául is a testvériség magatartását írja elő. Ennél is szokatlanabb, egészen egyedülálló, hogy a testvériség eszméje az irányadó Izráel népének az idegenhez, a 
jövevényhez füződő kapcsolatában is, aminek alapja egyrészt a zsidók történelmében rejlik: Isten szakadatlanul arra emlékezteti őket, hogy nem bánhatnak mostohán az idegennel, hiszen egykor ők maguk is jövevények voltak Egyiptom földjén (Mózes 3. könyve). Ugyanakkor más helyen - pl. Jób könyvében - az egyenlöség gondolata az ugyanazon Teremtőtől való származás okán fogalmazódik meg. Az ugyancsak Mózes 3. könyvében kimondott szeretet-parancs pedig az Újszövetség központi tanításává válik (Wolff, 2001).

A zsidó-keresztény antropológia szabadság-értelmezése összefügg az uralkodás és a testvériség kapcsán fentebb tett észrevételekkel. Ez nyilvánul meg többek között abban az isteni parancsban, hogy minden ötvenedik évben az adósok minden tartozása eltöröltetik, szabadon visszatérhetnek övéik közé, és visszakapják földjüket (Mózes 3. könyve). Ez jelenik meg számos zsoltárban, ahol Istenhez mint a nyomorultak mellett elkötelezett Szabadítóhoz könyörög a zsoltáros. S a szabadság is majd az Újszövetségben, Krisztusnak az embereket megváltó-megszabadító tettében nyeri el jelentésének teljességét. A szabadság, a személy autonómiája mint az ember Isten-képúségének záloga már több ókeresztény szerző mủveiben felfedezhető (Bugár M., 2013).

A keresztény antropológia körvonalai tehát már a korakereszténység időszakában kezdenek kirajzolódni. Forrása az a meggyőződés, hogy a Jézus személyében eljött Messiás elsősorban a korabeli társadalom kitaszítottjaival akart közösséget vállalni, és mint Isten „szenvedő szolgája”, kereszthalála révén új szövetséget köt a néppel. Bár alaptalan az a kortárs vád, mely szerint a jézusi tanok kizárólag az egyszerü emberek körében, a szegények, nők, gyermekek vagy rabszolgák között találtak követőkre, kétségtelen, hogy a korabeli források szerint a názáreti éppen ilyen emberekkel vette körül magát. A Jézus nyomában járók a korabeli társadalom kitaszítottjai: leprások, ördögtől megszállottak, prostituáltak, házasságtörők, tolvajok, különféle függőségek rabjai. Wresinski szerint a krisztusi örömhír elsősorban nekik szól, és Krisztus őróluk mondta, hogy elsők lesznek Isten országában. Közöttük élt, velük vállalt sorsközösséget, s ugyanolyan értetlen tekinteteket vont magára, sőt: ugyanúgy megbotránkoztatott, mint ma a legnagyobb nyomorúságban élő családok. Mindebben nem csupán olyan volt, mint ők: ő maga volt a kitaszított.

Az őskeresztény kor hívő közösségeiben megszüntek a társadalmi megkülönböztetések: a legváltozatosabb társadalmi rangú emberek lettek egymás testvérei - amit jól példáz, hogy a sírfeliratokon nemigen található utalás arra, hogy alattuk rabszolgasorban elhunyt nyugodna, illetve az, hogy voltak rabszolga származású püspökeik (Géczi, Stirling és Tüske, 2007). A közösség kötelességének tartotta, hogy gondoskodjon a szükséget szenvedőkről: a közöttük élő szegényekről, özvegyekről, árvákról. A keresztény testvériességből fakadó egyenlőségi eszmény kívánalmai szerint megosztották egymással javaikat: vagyonközösségben éltek.

Ugyanez az egységre törekvés fejeződik ki Wresinski (2010, 261. o.) szavaiban:

„A Mozgalom tagjai nem az ökumenizmus bajnokai. Nem hitünk tartalmában, hanem őszinteségünkben, a legszegényebbek melletti végsőkig való elszántságában próbáljuk meg napról napra megélni az egységet, melyet egyébként már korábban megtapasztaltunk, hiszen az egység ott van, ahol a legrászorultabb családok. Amikor rájuk figyelünk, biztosak lehetünk abban, hogy egységessé és egyenlővé válunk."

Az a jelmondat, melyet Wresinski a pappá szentelés alkalmára választott - „Evezz a nyílt vízre és vesd ki hálódat” -, híven tükrözi azt a szándékát, hogy a társadalom „,mélyvizébe", a legszegényebbek közé vesse magát. Sorsközösséget akar vállalni velük, hogy hozzájuk - és Krisztushoz hasonlóan maga is védtelenné, kiszolgáltatottá váljék. 
Wresinski számára ugyanis világos, hogy az evangéliumok Jézus-alakjában éppen a társadalom által meghurcolt és elutasított ember vonásai rajzolódnak ki. És amint Isten Krisztusban testesült meg, úgy testesül meg Krisztus a legnyomorultabb emberben. Szemében a valódi emberség mentes mindentől, ami nem tartozik lényegéhez, vagyis

„minden gazdasági, politikai és egyházi hatalomtól. Ilyen emberséggel pedig nem a gazdagok, hanem a legszegényebbek rendelkeznek. Az ő lelkük mélyén még nem sérült a lényeg. Ezért tudott Krisztus a legtermészetesebb módon testet ölteni bennük." (Wresinski, 2010, 38. o.)

Minthogy antropológiájának kulcsfogalma a legszegényebb, a mindenétől megfosztott ember - aki épp e sokszoros megfosztottsággal definiálható a legpontosabban -, célszerünek látszik, hogy világnézetét abból a két szempontból vizsgáljuk meg, hogy ő maga hogyan tekint rájuk, s hogy milyen viszonyulást tart kívánatosnak a társadalom részéről a mélyszegénységben élők iránt.

\section{A mélyszegénységben élő emberek négy üzenete}

Az a sajátos szemléletmód, amellyel Wresinski a mélyszegénységben élő emberre tekint, négy alapvető pontban foglalható össze.

Először: a legszerencsétlenebb ember a rá jellemző sokszoros megfosztottság ellenére - vagy még inkább: épp e megfosztottság révén - Isten tökéletes képmása. Más szóval, paradox módon éppen ez az állapot teszi lehetővé, hogy az ember-ség lényege tisztán, minden rárakódott hordaléktól mentesen mutatkozzon meg benne, $\mathrm{s}$ az egyetemes emberinek hiteles hordozójává váljék (Leclerc, 2004). Ez a jézusi tanítás, amely talán leginkább Máté evangéliuma (25. fejezet, 31-46. versek) nyomán ismert, a kereszténység fontos alapelvévé, Wresinski számára pedig egyenesen elvi sarokkővé vált.

Amikor Wresinski a nyomorban élő családokra néz, nem megoldásra váró problémákat, hanem szenvedő emberi lényeket lát bennük (Grieu, 2009), olyan teremtményeket, akiknek az életét Isten akarta, s akik ennélfogva - minden érdemtől függetlenül, csupán mert élnek - értékesek, fontosak; életüknek célja van. Második alaptétele tehát abban áll, hogy tárgy helyett alanynak tekinti őket, vagyis képesnek tartja őket arra, hogy önálló döntéseket hozzanak, és tetteikért felelősséget vállaljanak. De csak e társadalmi viszonyulás általánossá válása révén válhatnak képessé arra, hogy kiemelkedjenek elszigeteltségükböl, és először is személyes életük aktív alakítói, másodszor egymással egyezségre jutva közös életük valódi formálói legyenek, harmadrészt - de az előzőektől elválaszthatatlanul - társadalmi szereplővé, a társadalmi-politikai párbeszédben teljes jogú partnerekké váljanak. A személyiség megalkotása, az egyéni létében kiteljesedő, szabad ember mint érték és mint célkitüzés, a reneszánsz vitalista világképében jelenik meg, majd a felvilágosodás eszmerendszerében teljesedik ki. Azonban a Wresinski által elgondolt (nagykorú) személyiség eszméje szintén a keresztény tanítás - habár jóval később „felfedezett” - része, sőt, többen is ,a kereszténység legnagyobb hozzájárulásának tartják a filozófiához" (Tóth, 2006, 173. o.).

Wresinski számára elfogadhatatlan, hogy a Negyedik Világ szegényeit az őket stigmatizáló társadalmi megítélés „,szociális eseteknek”, „beilleszkedésre képteleneknek” vagy „,betegeknek” - s ami ebből következik: izolált problémáknak - tekintse. Antropológiájának harmadik sarkalatos pontja, hogy ő már a Noisy-le-Grand-i telepre érkezésekor közös identitást fedez fel bennük. Erre a közös identitásra építve gondolja el a legszegényebbek társadalmi-gazdasági és spirituális emancipációjának lehetőségét. 
„Úgy vélem, hogy az Önkéntes Szolgálat létével és tevékenységével nemcsak megalapozza, de egyben érvényesíti is a legszegényebbek jogait. Egyrészt kezdeményezője és kiindulópontja egy társadalmi programnak, másrészt valóra váltásában is úttörö szerepet vállal." (Wresinski, 2010, 271. o.)

Ez az emancipáció tehát szorosan összekapcsolódik az egész társadalom iránti elkötelezettséggel és az alapvető emberi jogok kérdésével:

„A Mozgalom minden megnyilvánulása a lakosság körében egyszersmind a jogok tanulási folyamata a családok, az Önkéntes Szolgálat és a társadalom számára. Leleplezik az igazságtalanságot, helyreállítják az igazságosságot és bebizonyítják, hogy mindez lehetséges." (Wresinski, 2010, 273. o.)

Az emberi jogok kérdése gazdag hagyományokra tekint vissza a francia közgondolkodásban. Elvei a felvilágosodás filozófusainak köszönhetően, gyakorlatba való átültetésének kezdetei a francia forradalom idején hatottak elöször a francia társadalom egészére. A forradalom egyik alapvető dokumentumának tekintett Emberi és polgári jogok nyilatkozata az ember egyéni és közösségi jogait definiálja, amikor az első cikkelye kimondja: „Minden ember szabadnak és jogokban egyenlőnek születik és marad; a társadalmi különbségek csakis a közösség szempontjából való hasznosságon alapulnak.” A nyilatkozat alapelvei a francia jog jelenleg is érvényben lévő alkotmányos elvei közé tartoznak, és számos esetben hivatkozási alapul szolgálnak törvényhozással kapcsolatos kérdésekben. Ugyancsak kiemelkedő és szempontunkból releváns dokumentum az ENSZ égisze alatt létrehozott Emberi Jogok Egyetemes Nyilatkozata, amelyet 1948-ban fogadott el a nemzetközi közösség a minden embert megillető alapvető jogokról. Meg kell említenünk, hogy emlékköve a párizsi Trocaderón található egy olyan másik emlékkő szomszédságában, melyet negyven évvel később Wresinski helyezett el több százezres tömeg jelenlétében, és melyre e szavakat vésette:

„Ahol az emberek arra vannak ítélve, hogy nyomorban éljenek, ott sérülnek az emberi jogok. Szent kötelességünk összefogni, hogy e jogoknak érvényt szerezzünk." (Wresinski, 2010, 2. o.)

Wresinski tehát szervesen és tudatosan kapcsolja mozgalmát az említett dokumentumok alapelveihez, s ugyanezt az egyetemes igényt fejezik ki a referenciául választott szövegrészlet utolsó sorai is:

„Végső soron erről szól az »Evezz a nyílt vízre és vesd ki hálódat!« parancsa: arról, hogy ne torpanjunk meg annak a társadalomnak a határainál, amelyben élünk, hanem foglaljuk el a világot." (Wresinski, 2010, 300. o.)

A közös identitás hangsúlyozása nyilvánul meg abban a tényben is, hogy bár Wresinski szóhasználatában a legszegényebbek számos néven tünnek fel ${ }^{2}$, 1968-tól kezdődően leggyakrabban azzal a névvel illeti öket, amelyet ö maga alkotott számukra, s amely azóta szerte a világon a népesség legmélyebb szegénységben élő csoportjainak megnevezésére szolgál: ők az ún. „Negyedik Világ”. A névadás kontextusaként meg kell jegyeznünk, hogy a legszegényebbek nyilvánosság elötti megszólalásának első lépéseként 1967-ben a Mozgalom Uj panaszfüzetek címmel kiadványt jelentet meg, melybe maguk a családok írnak. A füzet alcíme Egy nép megszólal, közvetlen inspirálója pedig az a nagy hatású manifesztum, amely Panaszfüzetek címmel eredetileg a francia forradalom előestéjén, Dufourny de Villiers (1739-1796) francia politikusnak köszönhetöen jelent meg, s amely 
a semmiféle képviselettel nem rendelkező „,negyedik rend” (,a szegény napszámosok, nyomorékok, nincstelenek, mindennemü szerencsétlenek") részére követelt társadalmi jogokat. A név tehát árulkodó: egyszerre utal a francia történelem „negyedik rend” és a modern kor „harmadik világ” elnevezésére. Főként pedig azt jelenti, hogy egy olyan csoportnak, amelynek helyzetét egyébként leginkább sokszoros megfosztottságával szokás jellemezni, explicit módon is pozitív identitást ad. A Negyedik Világot olyan sorsközösségnek: „nép”-nek tekinti, amely nem egyszerüen a társadalmi kapcsolatok, a gazdasági, társadalmi és kulturális jogokhoz való hozzájutás hiányán, hanem egy meghatározott csoporthoz való tartozáson, bizonyos történelmi örökségen és az ebből kinövő közös terven alapul (Wresinski, 2004). Annak a látásmódnak a logikájával, amellyel Edward Burnett Taylor a 19. század végén forradalmasította az európai kultúrantropológiát, olyan különálló „népet” lát bennük, melyről megszokott gondolati sémáinkat követve nem tudunk helyes megállapításokat tenni, mivel minden látszat ellenére még csak azonos nyelvet sem beszélünk velük. Pedig a magatartásukat meghatározó elvek nagyon is koherensek, szokásaik sajátos, de jól megragadható életbölcsességből táplálkoznak (Taylor, 1871).

Miközben nem győzi hangsúlyozni a szegények tudáshoz juttatásának fontosságát, újra és újra azt is kinyilvánítja, hogy a tudás áramlásának egyidejüleg van egy ellentétes iránya is, amely legalább ugyanilyen érvénnyel kell, hogy kifejtse hatását. Antropológiájában a mélyszegénységben élő ember negyedik alapvető ismérve tehát az, hogy sajátos, egyedülálló tudással rendelkezik, amely a tapasztalaton alapul, s ez fontos szerepet játszik társadalmi emancipációjában.

\section{A társadalom felelőssége a legszegényebbekkel szemben}

Az emberről alkotott vízióval összhangban Wresinski szemében a civil társadalomra háruló első kötelesség, hogy a nyomorban élö embert teljes jogú partnerként kezelje minden, a társadalmat általánosan érintő kérdésben. Kulcsfontosságú, nemcsak szimbolikus értelemben vett híd-szerep hárul e téren is az önkéntesekre, akik a „kint” és „,bent” közötti élő összekötő kapcsot jelentik. Ök azok, akik önként feladva addigi életük biztonságát hosszú távra kötelezik el magukat, és ebben a döntésben éppúgy fontos szerepet játszik a telepen talált nyomorúság, mint a nyomorban élő családokkal mindenét megosztó különös ember karizmatikus egyénisége. Belölük lesz az ATD - Negyedik Világ Mozgalmának „,kemény magja”.

A társadalom második felelőssége, hogy a hátrányos helyzetüek életével kapcsolatos bármely döntéshozatal alapja nem lehet más, mint a legszegényebbeknek adott prioritás. A Mozgalom különösen ügyel arra, hogy ne váljék hivatallá, hogy személyesen és direkt módon az egyes ember elérését célozza meg. Ezzel egy olyan társadalom elöképét kívánja megrajzolni, amelyben az a Másik a legfontosabb, akivel osztozni akarunk. Ugyanakkor az is világosan látszik, hogy a mélyszegénységben élő családok egyedül képtelenek változtatni helyzetükön. Az egyetlen megoldás, hogy a Mozgalom partnerekként kezeli őket, méghozzá olyan partnerekként, akik mindvégig őrzik kezdeményező szerepüket. Ehhez az kell, hogy legyen türelme kivárni azt az időt, amelyre a családoknak szükségük van ahhoz, hogy ők tüzzék ki azt a következő konkrét célt, amelynek az elérésére és az ezzel járó küzdelemre késznek érzik magukat.

E két követelményben együttesen jelenik meg egyrészt a kereszténységnek az az alapelve, mely szerint minden ember egyenlő Krisztusban, másrészt az ember társadalmi dimenziójának fontossága - ami ugyanakkor nem jelenti azt, hogy értékét az határozhatná meg, mennyire hasznos a társadalom számára.

Harmadszor ugyancsak a társadalomra hárul a Negyedik Világ mint közösség elismerése. Kezdetben ez a családot jelenti: a mindenétől megfosztott, nincstelen ember szá- 
mára ugyanis a család a szabadság egyetlen színtere, a mindennapi személyiségromboló konfliktusok ellenére az emberi méltóság megélésének egyetlen esélye (Leclerc, 2004). Ezért a Mozgalom minden lehetséges módon védelmezi a családok integritását.

Az első évek alapozó munkája után elötérbe kerül a mélyszegénységben élök tágabb közösségként, népként való elismerése. A Negyedik Világ Szabadegyetem megalapítása kísérlet arra, hogyan tud egy sajátos intézmény a társadalmi emancipáció színtere lenni azzal, hogy elismeri a mélyszegénységben élők közösségének tapasztalatokon alapuló tudását és teret ad e tudás megosztásának, átadásának (Defraigne Tardieu, 2009).

Az előzőekből logikusan következik a negyedik fontos feladat: a Negyedik Világ tudásának társadalmi elismerése. Wresinski hangsúlyozza, hogy a tudás lényege az átadás és átadhatóság. Ennek hiánya már önmagában kirekesztés. A feladat az, hogy olyan fórum jöjjön létre, és olyan közös nyelv, amely nyitva áll mindenki előtt, s amelyen megszólalva a résztvevők kölcsönösen gazdagíthatnák egymást.

Ehhez elöször is a hivatalos tudomány müvelőinek be kell látniuk saját tudásuk részlegességét, vagyis le kell mondaniuk arról a felvilágosodás óta mind általánosabbá váló - nem kevésbé hiten alapuló - vélekedésről, miszerint a tudományok segítségével megmagyarázható a világ, majd tudatos nyitással el kell fogadniuk azt a másfajta tudást, amely a legszegényebbektől származik. Ez a „másfajta”-ság a hivatalos tudomány szemszögéből nézve mitikus tudásnak minősülhet, ugyanakkor - amint azt fentebb megállapítottuk - koherens, jól megragadható tapasztalatokon alapul. A kiindulópont elfogadásával egy olyan antropológiához jutunk, amelyben különböző tudások illeszkednek egymásba - tehát nem arról van szó, hogy egyszerüen egymás mellé lennének helyezve vagy egyetlen modellre volnának redukálva. A megoldás egy olyan közös cselekvés, amely a mindinkább tudatosuló szükségletekhez igazodva reagál a valóságra (Leclerc, 2004). E kétféle

Ehhez elóször is a hivatalos tudomány múvelóinek be kell látniuk saját tudásuk részlegességét, vagyis le kell mondaniuk arról a felvilágosodás óta mind általánosabbá váló - nem kevésbé hiten alapuló - vélekedésról, miszerint a tudományok segítségével megmagyarázható a világ, majd tudatos nyitással el kell fogadniuk azt a másfajta tudást, amely a legszegényebbektól származik. Ez a „másfajta"-ság a hivatalos tudomány szemszögéból nézve mitikus tudásnak minốsülhet, ugyanakkor - amint azt fentebb megállapitottuk - koherens, jól megragadható tapasztalatokon alapul. A kiindulópont elfogadásával egy olyan antropológiához jutunk, amelyben különbözó tudások illeszkednek egymásba - tehát nem arról van szó, hogy egyszerúen egymás mellé lennének helyezve vagy egyetlen modellre volnának redukálva. A megoldás egy olyan közös cselekvés, amely a mindinkább tudatosuló szükségletekhez iga-

zodva reagál a valóságra (Leclerc, 2004). tudás közötti párbeszéd kialakításában és a tudások összehangolásában megint csak megkerülhetetlen az önkéntesek közvetítő szerepe, mely azon a tudáson alapul, hogy meg kell nyílniuk a legszegényebbek tanítása előtt. Elengedhetetlenül szükséges tehát, hogy ez a tudás három autonóm komponensből: az 
elméleti, tudományos megismerésnek, a mélyszegénységben élők tapasztalati tudásának és köztük élő, vagyis az életet velük megosztó önkéntesek cselekvésen alapuló tudásának összeadódásából jöjjön létre. Csak így, csak ezen az összetett tudáson alapulva mehet végbe az emancipálódás.

De ez a látásmód egyáltalán nem evidens sem a nyomorban élők, sem pedig az őket kívülről nézők számára. Tanítani kell rá mindkét felet. Wresinski meggyőződése szerint azért él sok család mélyszegénységben, mert a társadalom nem teszi lehetővé számukra a javakhoz való hozzájutást. Ugyanakkor ez nem annyira a társadalom kirekesztő szándékából, mint inkább a felőle érkező kérdésfeltevések és megközelítések inadekvát módjából fakad. A valódi megoldás felé vezető út első lépése az kell, hogy legyen, hogy gyökeresen más, nem a többségi társadalom logikájából következő, hanem a mélyszegénységben élők autonóm, tapasztalati tudásán alapuló megközelítést tesszük magunkévá. A következő pedig, hogy vállaljuk az ily módon megszerzett tudásból származó következményeket (Wresinski, 1992, 2004).

Mind a legszegényebbekről, mind a társadalomról alkotott kép alapján világosan látható, hogy Wresinski antropológiájának fontos alkotóeleme az európai gondolkodásban már Boccacciónál megjelenő, majd a felvilágosodás időszakában előtérbe kerülő tolerancia, vagy még inkább a világnézeti pluralizmus elfogadása, sőt bátorítása.

„[Az első önkéntesek egyike,] Bernadette nem pusztán nem hitt az egyházban, hanem ki nem állhatta, és számára a sors fintora, hogy én pap vagyok. [...] Ma is Bernadette testesíti meg számunkra a másik véleményének tiszteletben tartását, sőt a másként gondolkodóba vetett olyan mély bizalmat, amely saját jövőjét is a másik kezébe teszi. Hiszen a kialakulófélben lévő Önkéntes Szolgálathoz csatlakozni már kezdetben egyet jelentett azzal, hogy életünket a legszegényebbek, egyszersmind a többi önkéntes kezébe tesszük, akik másként gondolkodnak, mint mi. Azt jelentette, hogy semmiféle biztonságot nem tartunk fenn magunknak. Nem mindig tudjuk felmérni, mekkora bizalom, micsoda kockázatvállalás kell annak elfogadásához, hogy valaki olyan emberekkel ossza meg az életet, akik másként gondolkoznak, mint ő. Ez egyik módja annak, hogy egészen odaadjuk, kiszolgáltassuk magunkat, hogy a legszegényebbekéhez hasonló helyzetbe hozzuk saját magunkat. Talán emiatt váltott ki az Önkéntes Szolgálat annyi csodálatot s egyszersmind szégyenkezést." (Wresinski, 2010, 264. o.)

\section{Záró gondolatok}

Összegzésképpen elmondhatjuk, hogy Wresinski antropológiájában fontos szerepet játszanak a már a felvilágosodás és a francia forradalom korában megfogalmazott, alapvető politikai és személyes szabadságjogok, amelyek minden embert megilletnek. Mindenekfölött azonban azon a sarkalatos keresztény tanításon alapul, mely szerint minden ember egyedi, megismételhetetlen lény, akinek az élete minden egyéb érdemtől függetlenül - akár egyéni képességekről, akár társadalmi hasznosságról van szó - önmagában méltóságot hordoz és abszolút értelemben vett értéket képvisel. 


\section{Irodalomjegyzék}

Begasse de Dhaem, A. (2011): Théologie de filiation et universalité du salut. L'anthropologie théologique de Joseph Wresinski. Cerf, Paris.

Biblia. (1987) Református Zsinati Iroda Sajtóosztálya, Budapest.

Bugár M. István (2013): Szabadság, szeretet, személy. Az ókeresztény teológia antropológiai vetülete. Kairosz Kiadó, Budapest.

Defraigne Tardieu, G. (2009): L'université populaire Quart Monde. La construction du savoir émancipatoire. 2013. április 18-i megtekintés, http:// www.bibliotheque-numerique-paris 8 .fr/fre/ ref/103889/150984871/

Géczi János, Stirling János és Tüske László (2007): Bevezetés a müvelödéstörténetbe. 2015. január 17-i megtekintés, Magyar Elektronikus Könyvtár, http:// mek.oszk.hu/07400/07453/07453.pdf

Grieu, É. (2009): Refuser la misère, le Père Joseph Wresinski et ATD Quart Monde. Transversalités, 111. sz., juillet-septembre. 91-103. DOI: 10.3917/ trans.111.0091

\section{Jegyzetek}

${ }^{1}$ 1987-ben ezen a napon volt az (a tanulmányban később szóba kerülő) nagygyülés, amelyen Wresinski többszázezres tömeg jelenlétében és nevében követeli, hogy az Európai Unió tekintse hivatalosan a mélyszegénységet és a kirekesztést az emberi jogok megsértésének, majd az Emberi Jogok Egyetemes Nyi-
Leclerc, M. (2004): L'anthropologie du Père Joseph Wresinski: entre Philosophie et Théologie. In: Colloque international Joseph Wresinski. Acteur et prophète du peuple des pauvres. Éditions Quart Monde, Paris. 43-54.

Taylor, E. B. (1871): Primitive Culture. J. Murray, London.

Tóth Judit (2006): Test és lélek. Kairosz Kiadó, Budapest.

Wolff, H. W. (2001): Az Ószövetség antropológiája. Harmat Kiadói Alapítvány, Budapest.

Wresinski, J. (1992): Écrits et paroles aux volontaires. Éditions Quart Monde, Paris.

Wresinski, J. (2004): Culture et grande pauvreté. Éditions Quart Monde, Paris.

Wresinski, J. (2010): Szegények egyháza. Bencés Kiadó, Pannonhalma.

latkozata emlékkövének tőszomszédságában maga is emlékkövet helyez el.

2 'amoindris', 'décriés', 'écrasés', 'exclus', 'marginaux', 'misérables', 'mutilés', 'opprimés', 'rejetés', 'désespérés' stb. 